\title{
Influence of eucalyptus development under soil fauna
}

\author{
D. Boeno (D), R. F. Silva ${ }^{b}$ (D), H. S. Almeida ${ }^{*}$ (D), A. C. Rodrigues ${ }^{b}$ (D), M. Vanzan $^{b}$ (D) and \\ R. Andreazza ${ }^{d}$ \\ aDepartamento de Solos, Universidade Federal de Santa Maria - UFSM, Av. Roraima, 1000, Prédio 42, CEP 97105-900, \\ Santa Maria, RS, Brasil \\ ${ }^{\text {b}}$ Departamento de Ciências Agronômicas e Ambientais, Centro de Educação Superior Norte do Rio Grande do Sul, \\ Universidade Federal de Santa Maria - UFSM, Linha Sete de Setembro, s/n, CEP 98400-000, \\ Frederico Westphalen, RS, Brasil \\ ${ }^{c}$ Colégio Politécnico, Universidade Federal de Santa Maria - UFSM, Av. Roraima, 1000, Prédio 70, CEP 97105-900, \\ Santa Maria, RS, Brasil \\ ${ }^{d}$ Centro de Engenharias, Universidade Federal de Pelotas - UFPel, Rua Benjamin Constant, 989, CEP 96010-020, \\ Pelotas, RS, Brasil \\ *e-mail: hazaelsa@gmail.com
}

Received: June 30, 2018 - Accepted: March 8, 2019 - Distributed: May 31, 2020

(With 3 figures)

\begin{abstract}
In the implantation of forests, soil tillage can affect the soil fauna, but over the years, it is possible that forest development can recompose the biological indicators of soil quality. So, the aim of this study was to evaluate the influence of different periods of eucalyptus development on community of edaphic fauna. The experiment was carried out in forest areas in the municipality of Ametista do Sul, RS. The Experimental design was completely randomized with 6 treatments, once 4 of the treatments were with different ages of the Eucalyptus grandis (two, four, six and eight years after trasnplant - YAT); plus 2 control treatments: Native Forest and Soil Naked, with 7 collection points. To sample the edaphic fauna, it was used traps such as PROVID. Also, the edaphic fauna was sampled at the depth of 0-5 cm for the quantification of mites. It was carried out the counting of individuals at the level of order and family for the mites, the means of the groups were submitted to the Tukey test and comparisons by Orthogonal Contrasts and calculated indices of Biodiversity: Margalef Richness, Simpson dominance, Shannon diversity and Pielou uniformity. The results showed lower abundance of individuals in Naked soil, while the Native Forest presented the best Biodiversity indices. With eight years of implantation of eucalyptus there was recovered the biological quality of the soil expressed by the population of springtails. The population of oribatídeos mites increased expressively from the six years of implantation of eucalyptus.
\end{abstract}

Keywords: plenty of mites, forest areas, diversity of edaphic fauna.

\section{Influência do desenvolvimento do eucalipto sob a fauna edáfica}

\section{Resumo}

Na implantação de florestas, o revolvimento do solo pode simplificar a fauna edáfica, porém com o passar dos anos é possível que o desenvolvimento florestal possa recompor os indicadores biológicos de qualidade do solo. O objetivo deste trabalho foi avaliar a influência de diferentes períodos de desenvolvimento de eucalipto sobre a comunidade da fauna edáfica. $\mathrm{O}$ experimento foi realizado em área florestal no município de Ametista do Sul, RS. O delineamento experimental foi inteiramente casualizado com 6 tratamentos, sendo 4 tratamentos com diferentes períodos de implantação de Eucalyptus grandis (dois, quatro, seis e oito anos após o transplante - YAT) + 2 tratamentos controle - Mata Nativa e Solo Desnudo, com 7 pontos de coleta. A coleta da fauna edáfica foi por meio de armadilhas do tipo PROVID e amostras centrais de solo na profundidade de 0-5 cm para ácaros. Realizou-se a contagem de indivíduos em nível de classe ou ordem e de família para ácaros, as médias dos grupos foram submetidas ao teste de Tukey e comparações por Contrastes Ortogonais e calculados os índices de biodiversidade: Riqueza de Margalef, dominância de Simpson, Diversidade de Shannon e uniformidade de Pielou. Os resultados demonstram menor abundância de indivíduos no solo Desnudo, enquanto a Mata Nativa apresentou os melhores índices de Biodiversidade. Com oito anos de implantação de eucalipto ha recuperação da qualidade biológica do solo expressa pela população de Colêmbolos. A população de ácaros oribatídeos aumenta expressivamente a partir dos seis anos de implantação de eucalipto.

Palavras-chave: abundância de ácaros, áreas florestais, diversidade de fauna edáfica. 


\section{Introduction}

The genus of the Eucalyptus is the most planted tree in the world, because of it has adaptation to the different environmental conditions, besides the cycle is reduced and it has high productivity (Castro et al., 2016). In Brazil, eucalyptus cultivation occupies an area of more than 7,84 million hectares, due to the need for raw material by the furniture, paper, pulp and energy industry (IBÁ, 2018). However, there is a lack of studies related to the periods of development of eucalyptus with the occurrence and diversity of the edaphic fauna.

The edaphic fauna refers to organisms that inhabit the soil or that spend part of their life cycle on it (Assad, 1997) and constitutes with an important component in the biological processes that act in the decomposition of organic residues (Silva et al., 2011b), contributing to the nutrient cycling, improving physical properties of soil such as water infiltration and aeration through the construction of galleries (Ducatti, 2002).

The physico-chemical and biological effects of soil invertebrates can influence plant growth positively or negatively (Brown et al., 2006). Thus, the soil biota is considered responsible for maintaining the sustainability of the local environment, as it performs numerous of chemical and physical transformations of the organic material present on the soil surface (Souto et al., 2008).

The edaphic mesofauna organisms can act as soil quality bioindicators (Rieff et al., 2014), presenting a great diversity of species and with high influence on the environmental changes (Wahl et al., 2012). According to Heger et al. (2012), bioindicators are sensitive to natural changes or to human activities in the soil. The mites participate and perform nutrient renewal functions (Kautz et al., 2006), acting expressively in the regulation of the microbial population (Marion, 2011). They are organisms that live on the ground, making them important representatives of the local conditions and even possible changes, and also, they can be a good mechanism for the historical survey of the area as evaluation (Rieff et al., 2014).

The plants that compose the forest system perform the replenishment of the organic material in the soil through the litter, which consists of plant material coming from the aerial part of the plants, and it hosts a great diversity of terrestrial organisms (Zardo et al., 2010). In this sense, the areas with forest crops are favorable to the occurrence of edaphic organisms, with the Collembola, Blatodea: Termitoidea (Isoptera), Hymenoptera and Coleoptera groups being dominant (Silva et al., 2011a). However, monocultures provide a single food substrate favoring certain groups of soil fauna organisms, which may cause biological imbalance (Baretta et al., 2003). Thus, the soil fauna population can be directly affected by different vegetation covering the soil and management practices, due to the presence of organic residues on the soil surface (Silva et al., 2011a). In this way, the aim of this study was to evaluate the influence of different periods of development of eucalyptus on the macrofauna and mesoedaphic.

\section{Material and Methods}

The experiment was conducted in the Eucalyptus plantation in the municipalitie of Ametista do Sul, RS, Brazil, with coordinates: latitude of $27^{\circ} 22^{\prime} 15^{\prime \prime} \mathrm{S}$ and $53^{\circ} 07^{\prime} 27^{\prime \prime} \mathrm{W}$ of the Longitude with an average elevation of 443 meters for the areas of two, four and six years

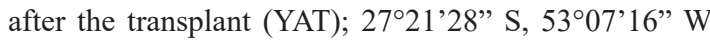
and average elevation of 432 meters for the eight YAT and $27^{\circ} 21^{\prime} 14^{\prime}$ S, $53^{\circ} 07^{\prime} 50^{\prime}$ ' $\mathrm{W}$ and average elevation of 368 meters for the area of soil naked. The soil of the site was characterized as the NEOSSOLO REGOLÍTICO Eutrófico léptico (Entisols Orthents Udorthents Typic Udorthents) (EMBRAPA, 2013) and with the following texture and chemical characteristics: $15 \%$ of clay, $49 \%$ of silt and $36 \%$ of sand; $\mathrm{pH}$ in water of $6.1 ; 3.6 \mathrm{mg} \mathrm{dm}^{-3}$ of P (Mehlich-1); $102 \mathrm{mg} \mathrm{dm}^{-3}$ of $\mathrm{K} ; 8.8 \mathrm{cmol} \mathrm{dm}^{-3}$ of $\mathrm{Ca} ; 3.3 \mathrm{cmol}_{\mathrm{c}} \mathrm{dm}^{-3}$ of $\mathrm{Mg} ; 2.1 \%$ of organic matter (EMBRAPA, 2011). The climate of the region is the type Cfa according to Köppen (Kuinchtner and Buriol, 2016). The annual average temperature is $19.8^{\circ} \mathrm{C}$, the average annual rainfall is $1860 \mathrm{~mm}$. The predominant relief varies from moderately declining to declining.

The cultivated species was the Eucalyptus grandis (Ex. Maiden), whose preparation for its implantation consisted in the soil revolving with ridges, with the seedlings transplanted 1667 of plants ha ${ }^{-1}$. The basic fertilizations was carried out according to the recommendation of the Manual of Fertilization and Liming for the states of RS and SC (CQFS, 2016). Weed control was carried out in the first eight months of crop implantation by means of brushing and desiccation with the herbicide Glyphosate.

The experimental design was completely randomized, where the treatments consisted of four different years old of cultivation of the eucalyptus at two ( $0.8 \mathrm{ha})$, four (1.5 ha), six ( $0.8 \mathrm{ha}$ ) and eight years (1.3 ha) after transplant (YAT), plus two comparative treatments, one of them being Naked soil (prepared for planting of eucalyptus) and an area of native forest near the areas of eucalyptus, whose area of 0.5 and 1.5 ha, respectively, totaling six treatments. In the areas with four, six and eight, the thinning of plants was performed, $33 \%$ of the previous number of plants being removed in each area, remaining 1117, 748 and 501 plants $\mathrm{ha}^{-1}$ in the respective areas.

The soil fauna was sampled with the PROVID traps (Antoniolli et al., 2006), containing a solution of $250 \mathrm{ml}$ of alcohol $70 \%$ for the conservation of the captured organisms, remaining in the field for a period of five days. Seven traps were spaced 10 meters from each other in the central position of each area. After five days, the traps were collected and sealed for transportation to the laboratory of Soil Biology of the Federal University of Santa Maria (UFSM) - Campus Frederico Westphalen. The edaphic organisms removed in the traps were identified at class or order level (Buzzi, 2008), with the aid of binocular loupes with a 60 times of increase.

The edaphic mesofauna was sampled with Kopeck rings, with a known volume of $98.17 \mathrm{~cm}^{-3}$, and two 
cylinders were sampled in each replicate. The soil samples were sent to the Laboratory of Soil Biology of the UFSM Soil Department for the extraction of the organisms by the Tullgren-Berlese funnel. The mites extracted were quantified and separated at the family level according to the methodology described by Moraes and Flechtmann (2008) and Krantz and Walter (2009).

After counting and identification of the organisms of the edaphic fauna and family for the mites, the following biodiversity indexes were calculated: abundance of individuals, which represents the sum of the occurrence of all groups of individuals in the sample, Margalef Richness index which represents the probability of individuals sampled in a given area belonging to different species, where $\mathrm{I}=\left[\left(\mathrm{n}^{-1}\right)\right] / \ln \mathrm{N}$, where $\mathrm{I}$ is the diversity, $\mathrm{n}$ is the number of species present, and $\mathrm{N}$ is the total number of individuals found in the sample. Simpson Dominance Index, measures the probability of two individuals, randomly selected in the sample, belonging to the same species calculated by $\mathrm{S}=\Sigma(\mathrm{ni} / \mathrm{N}) 2$, Shannon diversity index where $\mathrm{H}=-\Sigma \mathrm{Pi}$ $\log \mathrm{Pi}$, where $\mathrm{Pi}$ is the proportion of group $\mathrm{i}$ in the total of the sample (ni/N) and for the analysis of community uniformity the Pielou equability index was defined as: $\mathrm{e}=\mathrm{H} / \log \mathrm{S}$, where $\mathrm{H}$ corresponds to the Shannon index and $\mathrm{S}$ is the total number of groups in the community (Odum, 1988). The richness of the taxonomic groups indicates the number of groups presented in the treatment.

The presuppositions were analyzed, the residue distribution was verified and the homoscedasticity of the variances. The counting data were analyzed at the transformation $(\mathrm{x}+0.5)^{0.5}$ and the variables submitted to analysis of variance (Anova), the means of the groups collected with PROVID were submitted to the Tukey test and comparisons by Orthogonal Contrasts with significance level of $5 \%$, four contrasts were established: $\mathrm{C} 1=-0,2,4,6$ and 8 years + Native; $\mathrm{C} 2=-0,2,4$ and 6 years +8 years $($ Native $=0)$; $\mathrm{C} 3=-0$ year $+2,4,6,8($ Native $=0)$; $\mathrm{C} 4$ : - years + Native $(0,2,4$ and 6 years $=0)$, to show the effect of the period of development of eucalyptus with the control treatments (native forest and soil naked). The analyzes were performed using the SISVAR statistical program (Ferreira, 2008).

\section{Results and Discussions}

The results of the edaphic fauna from the PROVIDS revealed the presence of 3.644 individuals distributed in the Acarina, Aranae, Coleoptera, Collembola, Diptera, Hymenoptera, Lepidoptera (adults) and Orthoptera groups. The Coleoptera, Collembola and Hymenoptera orders showed the highest number of individuals in relation to the total population, with $15.34,29.88$ and $36.72 \%$, respectively; all these groups together, they represented $81.94 \%$ of the total organisms (Table 1). This result corroborates to those of Garlet et al. (2013) that verified in eucalyptus plantations higher proportions of organisms of the groups Coleoptera and Hymenoptera in relation to the total population.

In the Table 2, it shows the results of the comparison of averages by orthogonal contrasts of the areas with different periods of implantation of eucalyptus, native forest and Naked soil. For the Aranae group the contrasts were not significant. The both Acari and Lepidoptera groups, contrasts 2 and 3 were not significant, evidencing the influence of the native forest on the abundance of these organisms. For the group of Coleoptera and Hymenoptera, contrast 4 showed that eucalyptus cultivation with eight years old, the populations of these organisms are superior to those found in native forest.

The area with eight years old of implantation of eucalyptus presented the highest abundance of Collembola (springtails), being higher than the other treatments (Table 2). According to Rovedder et al. (2009), the springtails can be considered a group capable of expressing soil quality conditions. These individuals feed on fungi, being essential for nutrient cycling (Bellini and Zeppelini, 2009). Thus, a positive effect of eucalyptus with eight years of cultivation on the recovery of the springtails population is evidenced.

For the edaphic fauna groups, there is an increase in the number of individuals in areas with different eucalyptus

Table 1. Analysis among the treatments after transplantation of the eucaliptus (zero, two, four, six and eightyears old) and native forest (MN) for the number of organisms in the edaphic fauna groups (collected with PROVID), and frequency of the groups in percentage.

\begin{tabular}{|c|c|c|c|c|c|c|c|c|}
\hline Areas & Acar** & Ara & Coleo & Coll & Dipt & Hym & Lepi & Orth \\
\hline Native Forest & $2.00 \mathrm{a}^{*}$ & $2.29 \mathrm{a}$ & $14.71 \mathrm{bc}$ & $37.86 \mathrm{~b}$ & $15.43 \mathrm{a}$ & $35.71 \mathrm{a}$ & $2.00 \mathrm{a}$ & $9.86 \mathrm{a}$ \\
\hline 0 old & $0.00 \mathrm{~b}$ & $0.57 \mathrm{a}$ & $0.86 \mathrm{e}$ & $2.71 \mathrm{e}$ & $1.29 \mathrm{c}$ & $13.14 \mathrm{c}$ & $0.29 \mathrm{~b}$ & $1.14 \mathrm{~d}$ \\
\hline 2 old & $0.00 \mathrm{~b}$ & $2.14 \mathrm{a}$ & $10.57 \mathrm{~cd}$ & $8.71 \mathrm{~cd}$ & $5.57 \mathrm{~b}$ & $36.86 \mathrm{a}$ & $0.57 \mathrm{~b}$ & $6.71 \mathrm{~b}$ \\
\hline 4 old & $0.57 \mathrm{ab}$ & $1.00 \mathrm{a}$ & $14.43 \mathrm{~b}$ & $11.14 \mathrm{c}$ & $4.14 \mathrm{~b}$ & $24.14 b$ & $0.14 \mathrm{~b}$ & $5.00 \mathrm{bc}$ \\
\hline 6 old & $0.43 \mathrm{ab}$ & $2.00 \mathrm{a}$ & $8.29 \mathrm{~d}$ & $5.29 \mathrm{de}$ & $6.14 \mathrm{~b}$ & $41.29 \mathrm{a}$ & $0.57 \mathrm{~b}$ & $4.00 \mathrm{c}$ \\
\hline 8 old & $0.29 \mathrm{ab}$ & $2.57 \mathrm{a}$ & $26.29 \mathrm{a}$ & $88.29 \mathrm{a}$ & $3.86 \mathrm{bc}$ & $40.00 \mathrm{a}$ & $0.57 \mathrm{~b}$ & $11.29 \mathrm{a}$ \\
\hline $\mathrm{CV}^{* * *}(\%)$ & 45.03 & 38.7 & 9.34 & 6.91 & 15.01 & 5.42 & 29.9 & 13.58 \\
\hline Total & 0.63 & 2.03 & 15.34 & 29.88 & 7.3 & 36.72 & 0.8 & 7.3 \\
\hline
\end{tabular}

*Different letters in the columns are significantly different by Tukey test analysis at $5 \%$ of the error of probability; **Acar $=$ Acari; Ara=Aranha; Coleo=Coleoptera; Coll=Colêmbola; Dipt=Diptera; Hym=Hymenoptera; Lepi=Lepideptera; Orth=Orthoptera; $* * *$ Coefficient of variation. 
ages, compared to the Naked soil, excepted for the order of the Lepidoptera, which did not differ statistically between the treatments (Table 2). According to Melo et al. (2009) human interventions can affect the dynamics of edaphic fauna, as well as their functions in the environment. Thus, the diversity and activity of the edaphic fauna are reduced with soil uptake, due to the disintegration of the soil and lack of vegetation coverage, leading to reduced food availability and marked changes in the soil moisture and temperature (Alves et al., 2006; Bertol et al., 2004; Baretta et al., 2003).

The treatment with eight year old of eucalyptus presented incremental numbers of individuals of the orders Coleoptera, Collembola, Hymenoptera and Orthoptera, presenting statistical difference in relation to the other areas studied. (Table 2). The forestry systems provide a biological balance, with a controlled trophic structure and a better distribution of food among the different species, and tend to be an environment with less dominance of certain groups over the others (Begon et al., 2005). This shows that with 8 years of eucalyptus cultivation in monoculture, it manages to recover the population of important groups of the edaphic fauna in relation to the native forest.

When it is compared the native forest with other treatments with eucalyptus, it is observed that areas with the zero, two, four and six, year old of eucalyptus implantation had a lower number of fauna individuals than the native forest area and eight years of cultivation of eucalyptus, which was statistically the best treatment (Table 3). Maestri et al. (2013), which evaluated the richness of arthropods in eucalyptus and native forest areas, had found that $82.84 \%$ of the individuals were in the native forest. This is due to the areas with native forest promote favorable conditions to the establishment and development of the fauna of the soil, due to the greater deposition of leaves, providing stability in luminosity and humidity, thus benefiting more sensitive species (Canto, 1996).

The area with eucalyptus cultivation for eight years presented lower Margalef richness than the other areas (Table 3). Ferreira and Marques (1998) found values of Margalef richness higher in the forest area than in the eucalyptus. Silva et al. (2011b) and Almeida et al. (2017), found similar results for this index, finding a greater probability of individuals quantified in natural environments, belonging to different species. In this way, the native forest can be used as a standard for purposes of comparison of the impacts of different forms of management and agricultural and forest crops on the edaphic fauna.

The native forest area presented the highest Pielou equitability index, on the other side, the Naked soil presented the lowest value for this index (Table 3 ). The variability of the values for this index is due to the values of dominance and richness of the organisms, since this index will be higher when the dominance of some groups is low and the richness is high (Machado et al., 2015; Almeida et al., 2017). Machado et al. (2015), presented that the native environment allows a favorable place for the establishment of individuals, because of the complexity of the vegetation structure.

The highest diversity index of Shannon was at the native forestry area followed by areas with cultivation of eucalyptus by four and two years. This is due to the fact that in the initial periods after the implantation of eucalyptus, there is still a great diversity of vegetal residues

Table 2. Analysis of Orthogonal Contrasts in eucalyptus plantations at zero, two, four, six and eight years old after transplant, to the native forest (MN) for the number of organisms in the edaphic fauna groups.

\begin{tabular}{lcccccccc}
\hline Contrasts & Acar*** & Ara & Coleo & Coll & Dipt & Hym & Lepi & Orth \\
\hline Cont $1 * *$ & 1.74 & ns & ns & 14.63 & 11.23 & 4.62 & 1.57 & 4.23 \\
Cont 2 & ns* & ns & 17 & 81.32 & ns & 11.14 & ns & 7.07 \\
Cont 3 & ns & ns & 14.78 & 25.64 & 3.64 & 22.42 & ns & 5.61 \\
Cont 4 & 1.71 & ns & -11.57 & -50.43 & 11.57 & -4.29 & 1.43 & ns \\
\hline
\end{tabular}

*not significant; ${ }^{* *}$ Contrast $1=0,2,4,6$ and 8 years vs Native soil; Contrast $2=0,2,4$ and 6 years vs 8 years; Contrast $3=0$ year vs 2, 4, 6, and 8 years; Contrast $4=8$ years vs Native; $* * *$ Acar $=$ Acari; Ara $=$ spider; Coleo $=$ Coleoptera; Coll $=$ Collembola; Dipt=Diptera; Hym=Hymenoptera; Lepi=Lepideptera; Orth=Orthoptera.

Table 3. Abundance, Pielou Index, Richness, Shannon and Simpson Index, and the average number of fauna individuals sampled from the different Eucalyptus plantations (zero, two, four, six and eight years old) and native forest.

\begin{tabular}{lccccc}
\hline \multicolumn{1}{c}{ Areas } & Abun* & Piel & Ric & Shan & Simp \\
\hline Native Forest & $119.9 \mathrm{~B}$ & 0.089 & 1.37 & 0.71 & 0.23 \\
0 old & $24.9 \mathrm{D}$ & 0.053 & 1.18 & 0.43 & 0.48 \\
2 old & $71.1 \mathrm{C}$ & 0.077 & 1.14 & 0.62 & 0.32 \\
4 old & $63.6 \mathrm{C}$ & 0.081 & 1.28 & 0.65 & 0.26 \\
6 old & $68.0 \mathrm{C}$ & 0.070 & 1.29 & 0.56 & 0.41 \\
8 old & $173.1 \mathrm{~A}$ & 0.071 & 1.03 & 0.56 & 0.34 \\
CV** $(\%)$ & 11.25 & - & - & - & -
\end{tabular}

*Abun = Abundance; Piel $=$ Pielou; Ric $=$ Richness of the Margalef; Shan $=$ Shannon index $;$ Simp $=$ Simpson index; **Coefficient of variation. 
growth because the canopy of the eucalyptus still allows a good passage of light. In the naked soil area there was no presence of plant residues, so few groups of organisms can establish their population, and in the native forest area the greatest shannon diversity is due to the great availability and diversity of plant residues. Tews et al. (2004) showed that the greater diversity of groups can provide a greater amount of exploitation of the environmental resources, with the contribution of a more diversified covered with vegetation. According to Garlet et al. (2013), the increase in the deposition of plant material, due to the increase in the age of forest stands, provides better conditions for the development of edaphic fauna. Almeida et al. (2017), in a study with different cropping systems showed that the native forest presented the highest value for this index, stating such result is due to the diversity of vegetal material contributed to the soil.

The area with Naked soil was the one with the highest dominance of Simpson, followed by the area with six years of cultivation with the eucalyptus (Table 3 ), it is a result of the expressive presence of the Hymenoptera order. Ants have been considered as soil bioindicators, or indicators of stress environments (Sobrinho and Schoereder, 2007). The initial soil rotation prior to transplanting of eucalyptus causes soil exposure by incorporation in depth, favoring the occurrence of opportunistic organisms and adapted to this type of environment, in the same way as the lower input of plant material on the soil (Table 3).

The area with eight years of culture obtained a greater presence of the group of microphages (Figure 1), due to the expressive presence of springtails. The long-term cultivations of forest species, as they present a greater diversity of species of the soil fauna, are related to their function of regulating the microbial population, since they develop predatory activity of other microorganisms (Tordoff et al., 2008; Siddiky et al., 2012). The long-term cultivations with forestry species can provide a much higher diversity and amount of litter and it can be a source of nutrients as well as a refuge against predatory organisms (Canto, 1996).

The presence of the functional group of the social insects is related to the ant population found in the areas, justifying the high frequency of this group in the areas of Naked soil, two, four and six years old of eucalyptus cultivation (Figure 1). According to Guariguata and Ostertag (2001), forest systems provide changes in habitat over time such as biomass increase, nutrient availability and decrease in luminous intensity. The importance of ants is related to their function in the nutrient cycling, besides polinization and plants dispersion (Cantarelli et al., 2015). In this context, with the passage of time and the supply of organic material, the functional groups are changing with the tendency of microphages.

\section{Occurrence and Miversity of Mites}

The Native forestry area presented the highest number of mites (Table 3), due to its complexity and abundance of organic material, which favors the occurrence of a larger population of organisms, with different vegetal residues and adequate climatic conditions. Sousa et al. (2004) attributed greater diversity of native forest organisms to greater heterogeneity and complexity in their habitat, greater variety and availability of organic material and possibility of haven against predators (Almeida et al., 2017).

In the evaluation of mites, it wase found 147 individuals and identified six families such as: Nothridae, Oribatida (suborder), Phthiracaridae, Pachylaelapidae, Galumnidae and Uropodidae. In the area of native forest and eucalyptus cultivated with 2 years old, it was verified the presence of 5 families of mites, having the largest number of families in relation to the other areas evaluated in this

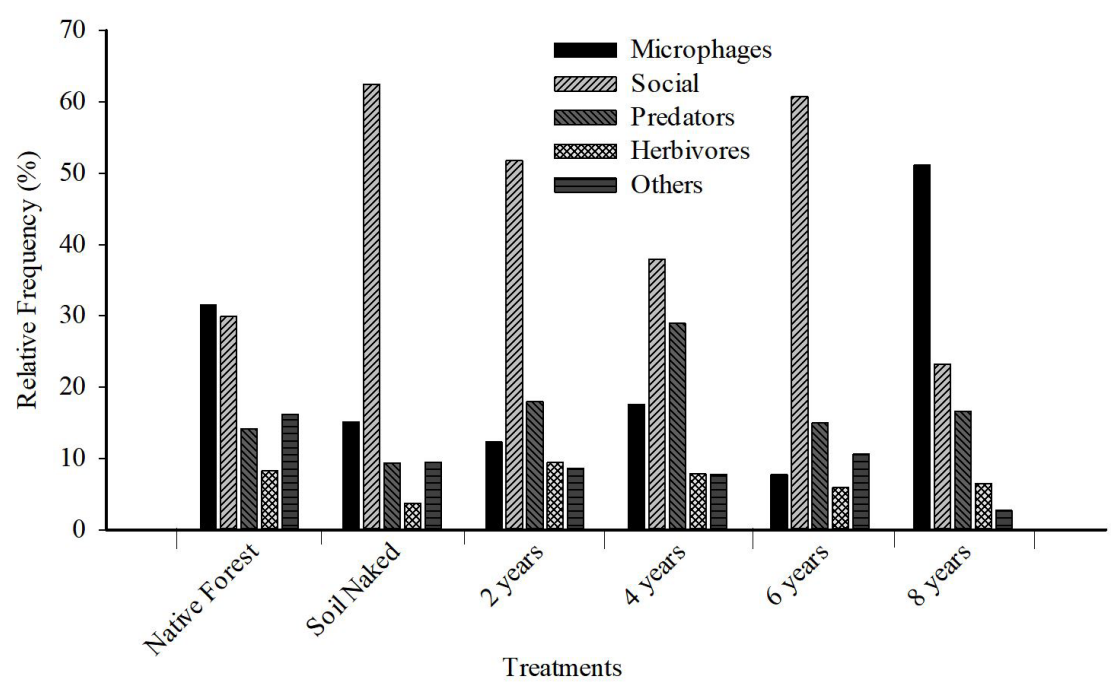

Figura 1. Relative Frequency (\%) of Functional Groups of Fauna Edáfica in the areas of Native Forest, Naked Soil, two, four, six and eight years old of Eucalyptus cultivation. 


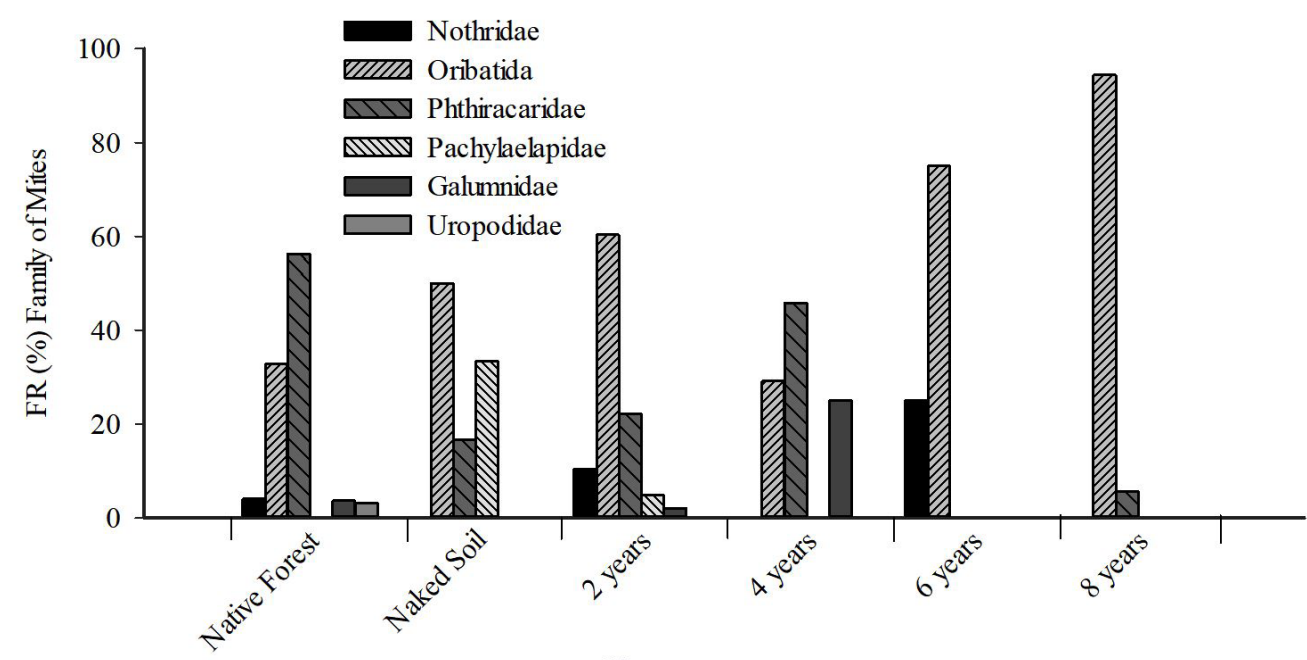

Treatments

Figure 2. Relative frequency (\%) of mite families in the areas of Native forestry, Naked Soil, two, four, six and eight years old of Eucalyptus cultivation.

study (Figure 2). Rovedder et al. (2009) related the greater diversity of mite families in the native environment due to the presence of diversity of litter, lower variation of soil temperature, moisture retention, diversification in the food source, among others.

It is observed the presence of mites of the Pachylaelapidae family only in the area of naked soil and the area with cultivation of eucalyptus with 2 years old plants, with the highest proportion of FR (\%) verified in the area of naked soil. Rieff et al. (2010) points out that the changes in vegetation cover can favor certain groups of organisms to the detriment of others. This family of mites is dependent on the complexity of plant material and it has the habit of migration, therefore, with soil revolving and beginning of establishment of eucalyptus, the predominance of this extract of vegetation, these organisms migrate to places with greater complexity of covering with vegetals.

In the area of native forestry, the family Phthiracaridae presented the highest proportion, in the same area was found the family Uropodidae (Figure 1). The higher relative frequency of Phthicariedae is corroborated by Berch et al. (2007), who observed the occurrence of this family in a forestry area. The Uropodidae family is among the taxa most dependent on the quality and availability of organic matter (Andrés, 1999). The presence of organic matter, absence of soil tillage, and greater protection against moisture variations are factors that favor the occurrence of mites in the Native forestry (Figure 2).

With the increase in age of the eucalyptus cultivation there was an increase in the presence of decomposing mites, especially in the Oribatida suborder, which presented more than $90 \%$ of the mites found in this family (Figure 2). The Oribatida are widely distributed, present high diversity, and are present in well structured soils.
Also, these organisms are secundary decompositors and they do a fragmentation on organic residues increasing the surface to microorganisms attach the residues, and also they are considered as bioindicators for soil quality (Franklin et al., 2007; Rieff et al., 2010; Minor, 2011; Almeida et al., 2017).

In the areas of eucalyptus cultivation, the Simpson dominance index increased at six and eight years old of Eucalyptus implantation and consequently decreased Shannon diversity (Figure 3). This is due to the increase in the population of oribatídeos mites, which act as soil organic matter decomposers (Berude et al., 2015), which represents a recovery of soil conditions. Nunes et al. (2018), in their work on different vegetative gradients, state that different times of the year influence the dynamics of edaphic mites. According to Franklin et al. (2007), this group is an indicator of soil quality. The increase of the deposition of organic material and its decomposition promoted an increase in the population of oribatídeos mites.

The rate of Pielou equitability was higher in the Native Forestry area (0.45), similar to the two and four year old of eucalyptus implantation areas and presented a significant reduction at six and eight years old of Eucalyptus implantation (Figure 3) Rieff et al. (2014) found in the native forestry area, at the 2013 year the highest value of the index (0.93). However, José et al. (2013) found a value of 1.99 in the minimum cultivation of the tobacco crop and in the native forestry a value of 1.77 .

The area with four years old of cultivation of eucalyptus was the one with the highest Margalef richness of mites (1.26) (Figure 3). Hoffmann et al. (2009) demonstrated that native forest areas showed a great diversity of mesofauna species, especially of mites. However, according to the Margalef index, values below 2 are denoted as low diversity, 


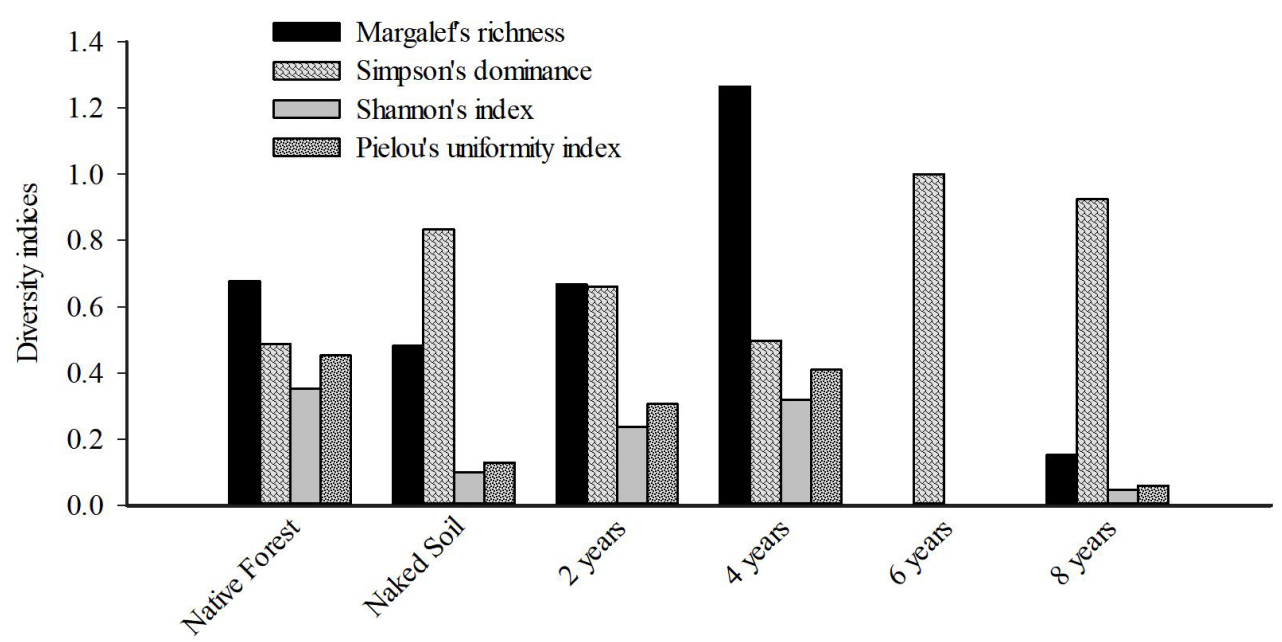

Figure 3. Margalef richness index, Simpson dominance, Shannon diversity and Pielou uniformity of mite families in the Native Forestry, Naked Soil and two, four, six and eight year old of Eucalyptus implantation.

in this way, in all studied areas, the eucalyptus areas presented changes in the richness of the mite population, which the cover of vegetation of the eucalyptus crop may harm or promote some families of mites, thus predicting that the population fluctuation can be used as a soil quality bioindicator.

\section{Conclusions}

With eight years of eucalyptus implantation, there is a recovery of the biological quality of the soil, as there is a strong increase in the abundance of edaphic organisms, and an increase in the population of Coleoptera, Colembolla, Hymenoptera and Orthoptera.

The relative frequency of the functional groups was more stable in the native forest, already to the area with eight years of eucalyptus cultivation, the functional group of micropages was the one that presented the greatest proportion.

The population of oribatídeos and Phthiracaridae mites are the ones that present the highest frequency in areas of eucalyptus plantations, and may be considered the indicator mites of biological quality of the soil.

\section{References}

ALMEIDA, H.S., SILVA, R.F., GROLLI, A.L., and SCHEID, D.L., 2017. Ocorrência e diversidade da fauna edáfica sob diferentes sistemas de uso do solo. Revista Brasileira de Tecnologia Agropecuária, vol. 1, no. 1, pp. 15-23.

ALVES, M.V., BARETTA, D. and CARDOSO, E.J.B.N., 2006. Fauna edáfica em diferentes sistemas de cultivo no estado de São Paulo. Revista de Ciências Agroveterinárias, vol. 5, no. 1, pp. 33-43.

ANDRÉS, P., 1999. Ecological risks of the use of sewage sludge as fertilizer in soil restoration: effects on the soil microarthropod populations. Land Degradation \& Development, vol. 10, no. 1, pp. 67-77. http://dx.doi.org/10.1002/(SICI)1099145X(199901/02)10:1<67::AID-LDR322>3.0.CO;2-H.
ANTONIOLLI, Z.I., CONCEIÇÃO, P.C., BÖCK, V., PORT, O., SILVA, D.M. and SILVA, R.F., 2006. Método alternativo para estudar a fauna do solo. Ciência Florestal, vol. 16, no. 4, pp. 407-417. http://dx.doi.org/10.5902/198050981922.

ASSAD, M.L.L., 1997. Fauna do solo. In: M.A.T. VARGAS and M. HUNGRIA. Biologia dos solos dos cerrados. Planaltina: EMBRAPA-CPAC, pp. 363-443.

BARETTA, D., SANTOS, J.C.P., MAFRA, A.L., WILDNER, L.P., and MIQUELLUTI, D.J., 2003. Fauna edáfica avaliada por armadilha e por catação manual afetada pelo manejo do solo na região Oeste Catarinense. Revista de Ciências Agroveterinárias, vol. 2, no. 2, pp. 97-106.

BEGON, M., TOWNSEND, C.R. and HARPER, J.L., 2005. Ecology from individuals to ecosystems. Malden: Black well Publishing, pp. 738.

BELLINI, B.C. and ZEPPELINI, D., 2009. Registros da fauna de Collembola (Arthropoda, Hexapoda) no estado da Paraíba, Brasil. Revista Brasileira de Entomologia, vol. 53, no. 3, pp. 386-390. http://dx.doi.org/10.1590/S0085-56262009000300012.

BERCH, S.M., BATTIGELLI, J.P. and HOPE, G.D., 2007. Responses of soil mesofauna communities and oribatid mite species to site preparation treatments in high elevation cut blocks in southern British Columbia. Pedobiologia, vol. 51, no. 1, pp. 23-32. http://dx.doi.org/10.1016/j.pedobi.2006.12.001.

BERTOL, I., ALBUQUERQUE, J.A., LEITE, D., AMARAL, A.J. and ZOLDAN JUNIOR, W.A., 2004. Propriedades físicas do solo sob preparo convencional e semeadura direta em rotação e sucessão de culturas, comparadas às do campo nativo. Revista Brasileira de Ciência do Solo, vol. 28, no. 2, pp. 155-163. http:// dx.doi.org/10.1590/S0100-06832004000100015.

BERUDE, M.C., GALOTE, J.K.B., PINTO, P.H. and AMARAL, A.A., 2015. A mesofauna do solo e sua importância como bioindicadora. Enciclopédia Biosfera, vol. 11, no. 4, pp. 14-28.

BROWN, G.G., ROMBKE, J., HOFER, H., VERHAAGH, M., SAUTTER, K.D., and SANTANA, D.L.Q., 2006. Biodiversity and function of soil animals in Brazilian agroforestry systems. In: A.C. GAMA-RODRIGUES, N.F. BARROS, E.F. GAMA- 
RODRIGUES, M.S.M. FREITAS, A.P. VIANA, J.M. JASMIN, C.R. MARCIANO and J.G.A. CARNEIRO, eds. Sistema agroflorestais: bases cientificas para o desenvolvimento sustentável. Campos dos Goytacazes: Universidade Estadual do Norte Fluminense, pp. $217-242$

BUZZI, Z.J., 2008. Entomologia didática. 4. ed. Curitiba: Editora UFPR, $348 \mathrm{p}$.

CANTARELli, E.B., FLECK, M.D., GRANZOTTO, F., CORASSA, J.D.N. and D'AVILA, M., 2015. Diversidade de formigas (Hymenoptera:Formicedae) da serapilheira em diferentes sistemas de uso do solo. Ciência Florestal, vol. 25, no. 3, pp. 607-616. http://dx.doi.org/10.5902/1980509819612.

CANTO, A.C., 1996. Alterações da mesofauna do solo causadas pelo uso de cobertura com plantas leguminosas na Amazônia Central. Revista de Ciências Agrárias (Belém), vol. 4, no. 5, pp. 79-94.

CASTRO, C.A.O., RESENDE, R.T., BHERING, L.L., and CRUZ, G.D., 2016. Brief history of Eucalyptus breeding in Brazil under perspective of biometric advances. Ciência Rural (Santa Maria), vol. 46, no. 9, pp. 1585-1593.

COMISSÃO DE QUÍMICA E FERTILIDADE DO SOLO CQFS, 2016. Manual de calagem e adubação para os Estados do Rio Grande do Sul e Santa Catarina. 11. ed. Porto Alegre: SBCS/NRS, $376 \mathrm{p}$.

DUCATTI, F., 2002. Fauna edáfica em fragmentos florestais e em áreas reflorestadas com espécies da mata atlântica. Piracicaba: Escola Superior de Agricultura "Luiz de Queiroz", Universidade de São Paulo, 84 p. Dissertação de Mestrado.

EMPRESA BRASILEIRA DE PESQUISAAGROPECUÁRIAEMBRAPA, 2011. Manual de métodos de análises de solo. 2. ed. Rio de Janeiro: Ministério da Agricultura e do Abastecimento, $225 \mathrm{p}$.

EMPRESA BRASILEIRA DE PESQUISAAGROPECUÁRIAEMBRAPA, 2013. Sistema brasileiro de classificação de solos. Brasília: Embrapa Produção de Informações, 353 p.

FERREIRA, D.F., 2008. SISVAR: um programa para análises e ensino de estatística. Revista Symposium, vol. 6, pp. 36-41.

FERREIRA, R.L. and MARQUES, M.G.S.M., 1998. A fauna de artrópodes de serrapilheira de áreas de monocultura com Eucalyptussp. e mata secundária heterogênea. Anais da Sociedade Entomológica do Brasil, vol. 27, no. 3, pp. 395-403. http://dx.doi. org/10.1590/S0301-80591998000300007.

FRANKLIN, E., SANTOS, E.M.R. and ALBULQUERQUE, M.I.C., 2007. Edaphic and arboricolousoribatid mites (Acari; Oribatida) in tropical environments: changes in the distribution of higher level taxonomic groups in the communities of species. Brazilian Journal of Biology $=$ Revista Brasileira de Biologia, vol. 67 , no. 3, pp. 447-458. http://dx.doi.org/10.1590/S151969842007000300009 . PMid:18094827.

GARLET, J., COSTA, E.C. and BOSCARDIN, J., 2013. Caracterização da fauna edáfica em plantios de Eucalyptus spp. Ciência Florestal, vol. 23, no. 3, pp. 337-344. http://dx.doi. org/10.5902/1980509810545.

GUARIGUATA, M.R. and OSTERTAG, R., 2001. Neotropical secondary succession: changes in structural and functional characteristics. Forest Ecology and Management, vol. 148, no. 1, pp. 85-206. http://dx.doi.org/10.1016/S0378-1127(00)00535-1.

HEGER, T., IMFELD, G. and MITCHELL, E.A.D., 2012. Special issue on "bioindication in soil ecosystems": editorial note. European Journal of Soil Biology, vol. 49, pp. 1-4. http:// dx.doi.org/10.1016/j.ejsobi.2012.02.001.

HOFFMANN, R.B., NASCIMENTO, M.S.V., DINIZ, A.A., ARAÚJO, L.H.A., and SOUTO, J.S., 2009. Diversidade da mesofauna edáfica como bioindicadora para o manejo do solo em areia. Revista Caatinga, vol. 22, no. 3, pp. 684-692.

INDÚSTRIA BRASILEIRA DE ÁRVORES - IBÁ, 2018. Anuário estatístico IBÁ 2018 ano base 2017. Brasília: IBÁ.

JOSÉ, J.B.S., RIEFF, G.G. and SÁ, E.L.S., 2013. Mesofauna edáfica e atividade microbiana em diferentes sistemas de manejo do solo na cultura do tabaco. Current Agricultural Science and Technology, vol. 19, pp. 56-66.

KAUTZ, T., LÓPEZ-FANDO, C. and ELLMER, F., 2006. Abundance and biodiversity of soil microarthropods as influenced by different types of organic manure in a longterm field experiment in Central Spain. Applied Soil Ecology, vol. 33, no. 3, pp. 278-285. http://dx.doi.org/10.1016/j.apsoil.2005.10.003.

KRANTZ, G.W. and WALTER, D.E., 2009. A manual of acarology. 3rd ed. Texas: Texas Tech University Press, 807 p.

KUINCHTNER, A. and BURIOL, G.A., 2016. Clima do Estado do Rio Grande do Sul segundo a classificação climática de Köppen e Thornthwaite. Disciplinarum Scientia Naturais e Tecnológicas, vol. 2, no. 1, pp. 171-182.

MACHADO, M.L., PEREIRA, M.G., CORREIA, M.E.F., DINIZ, A.R. and MENEZES, C.E.G., 2015. Fauna edáfica na dinâmica sucessional da mata atlântica em floresta estacional semidecidual na bacia do Rio Paraíba do Sul - RJ. Ciência Florestal, vol. 25, no. 1, pp. 91-106. http://dx.doi.org/10.5902/1980509817466.

MAESTRI, R., LEITE, M.A.S., SCHMITT, L.Z. and RESTELLO, R.M., 2013. Efeito de mata nativa e bosque de Eucalipto sobre a riqueza de artrópodos na serrapilheira. Perspectiva, vol. 37, pp. 31-40.

MARION, L.F., 2011. Avaliação da qualidade do solo em propriedades agricolas familiares em sistema de cultivo convencional e de bases ecológicas, Santa Cruz do Sul, RS, Brasil. Santa Cruz do Sul: Universidade de Santa Cruz do Sul. Dissertação de Mestrado em Tecnologia Ambiental.

MELO, F.V., BROWN, G.G., CONSTANTINO, R., LOUZADA, J.N.C., LUIZÃO, F.J., MORAIS, J.W. and ZANETTI, R., 2009. A importância da meso e macrofauna do solo na fertilidade $e$ como bioindicadores. Biologia do solo. Viçosa: SBCS, Boletim informativo da SBCS, $5 \mathrm{p}$.

MINOR, M.A., 2011. Spatial patterns and local diversity in soil oribatid mites (Acari: Oribatida) in three pine plantation forests. European Journal of Soil Biology, vol. 47, no. 2, pp. 122-128. http://dx.doi.org/10.1016/j.ejsobi.2011.01.003.

MORAES, G.J. and FLECHTMANN, C.H.W., 2008. Manual de acarologia, acarologia básica e ácaros de plantas cultivadas no Brasil. Ribeirão Preto: Holos Editora, 308 p.

NUNES, L. A. P. L., ARAÚJO, A. S. F., PESSOA, M. M. C., SOUSA, R. S., SILVA, J. D. C. and MATOS-FILHO, C. H. A., 2018. Edaphic fauna in a vegetation gradient in the Sete Cidades National Park. Brazilian Journal Biology, vol. 79, no. 1, http:// dx.doi.org/10.1590/1519-6984.174135.

ODUM, E.P., 1988. Ecologia. Rio de Janeiro: Guanabara Koogan, 446 p.

RIEFF, G.G., MACHADO, R.G., STROSCHEIN, M.R.D. and SÁ, E.L.S., 2010. Diversidade de famílias de ácaros e colembolos 
edáficos em cultivo de eucalipto e áreas nativas. Revista Brasileira de Agrociencia, vol. 16, pp. 57-61.

RIEFF, G.G., NATAL-DA-LUZ, T., SOUSA, J.P. and SÁ, E.L.S., 2014. Diversity of springtails and mites of a native forest in southem Brazil: relationship with the índices of temperature and precipitation in the native environment. International Journal of Emerging Technology and Advanced Engineering, vol. 4, pp. 684-692.

ROVEDDER, A.P.M., ELTZ, F.L.F., DRESCHER, M.S., SCHENATO, R.B. and ANTONIOLLI, Z.I., 2009. Organismos edáficos como bioindicadores da recuperação de solos degradados por arenização no Bioma Pampa. Ciência Rural, vol. 39, no. 4, pp. 1061-1068. http://dx.doi.org/10.1590/S0103-84782009005000023.

SIDDIKY, M.D., KOHLER, J., COSME, M. and RILLIG, M.C., 2012. Soil biota effects on soil structure: interactions between arbuscularmycorrizal fungal mycelium and collembolan. Soil Biology \& Biochemistry, vol. 50, pp. 33-39. http://dx.doi. org/10.1016/j.soilbio.2012.03.001.

SILVA, M.A., SILVA, M.L.N., CURI, N., AVANZI, J.C. and LEITE, F.P., 2011a. Sistemas de manejo em plantios florestais de eucalipto e perdas de solo e água na região do vale do Rio Doce, MG. Ciência Florestal, vol. 21, no. 4, pp. 765-776. http:// dx.doi.org/10.5902/198050984520.

SILVA, R.F., SAIDELLES, F.L.F., VASCONCELLOS, N.J.S., WEBBER, D.P. and MANASSERO, D., 2011b. Impacto do fogo na comunidade da fauna edáfica em florestas de Eucaliptus grandis e Pinus taeda. Revista Brasieira de Agrociência, vol. 17, no. 2-4, pp. 234-241.

SOBRINHO, T. and SCHOEREDER, J.H., 2007. Edge and shape effects on ant (Hymenoptera: Formicidae) species richness and composition in forest fragments. Biodiversity and Conservation, vol. 16, no. 5, pp. 1459-1470. http://dx.doi.org/10.1007/s10531-006-9011-3.
SOUSA, J.P., GAMA, M.M., PINTO, C., KEATING, A., CALHÔA, F., LEMOS, M., CASTRO, C., LUZ, T., LEITÃO, P. and DIAS, S., 2004. Effects of land-use on Collembola diversity patterns in a Mediterranean landscape. Pedobiologia, vol. 48, no. 5-6, pp. 609-622. http://dx.doi.org/10.1016/j.pedobi.2004.06.004.

SOUTO, P.C., SOUTO, J.S., MIRANDA, J.R.P., SANTOS, R.V. and ALVES, A.R., 2008. Comunidade microbiana e mesofauna edáficas em solo sob catinga no semi-árido da Paraíba. Revista Brasileira de Ciência do Solo, vol. 32, no. 1, pp. 151-160. http:// dx.doi.org/10.1590/S0100-06832008000100015.

TEWS, J., BROSE, U., GRIMM, V., TIELBÖRGER, K., WICHMANN, M.C., SCHWAGER, M. and JELTSCH, F., 2004. Animal species diversity driven by habitat heterogeneity/ diversity: the importance of keystone structures. Journal of Biogeography, vol. 31, no. 1, pp. 79-92. http://dx.doi.org/10.1046/j.03050270.2003.00994.x.

TORDOFF, G.M., BODDY, L. and JONES, T.H., 2008. Speciesspecific impacts of collembola grazing on fungal foraging ecology. Soil Biology \& Biochemistry, vol. 40, no. 2, pp. 434-442. http:// dx.doi.org/10.1016/j.soilbio.2007.09.006.

WAHL, J.J., THERON, P.D. and MABOETA, M.S., 2012. Soil mesofauna as bioindicators to assess environmental disturbance at a platinum mine in South Africa. Ecotoxicology and Environmental Safety, vol. 86, pp. 250-260. http://dx.doi. org/10.1016/j.ecoenv.2012.09.027. PMid:23099294.

ZARDO, D.C., CARNEIRO, Â.P., LIMA, L.G. and SANTOS FILHO, M.D., 2010. Comunidade de artrópodes associada à serrapilheira de cerrado e de mata de galeria, na estação ecológica serra das araras - Mato Grosso do Sul, Brasil. Revista Uniara, vol. 13, no. 2, pp. 105-113. http://dx.doi.org/10.25061/2527-2675/ ReBraM/2010.v13i2.143. 